\title{
RRx-001-Induced Tumor Necrosis and Immune Cell Infiltration in an EGFR Mutation-Positive NSCLC with Resistance to EGFR Tyrosine Kinase Inhibitors: A Case Report
}

\author{
Christina Brzezniak $^{a} \quad$ Bruno A. Schmitz $^{a}$ Paul G. Peterson ${ }^{a}$ \\ Aiste Degesys $^{a} \quad$ Bryan T. Oronsky $^{b}$ Jan J. Scicinski ${ }^{b} \quad$ Scott Z. Caroen ${ }^{b}$ \\ Corey A. Carter ${ }^{a}$
}

${ }^{a}$ Walter Reed National Military Medical Center, Bethesda, Md., and ${ }^{b}$ EpicentRx, Inc., Mountain View, Calif., USA

\section{Key Words}

Epidermal growth factor receptor $\cdot$ Non-small cell lung cancer $\cdot$ RRx-001

\begin{abstract}
We present the case of a 49-year-old male with metastatic epidermal growth factor receptor (EGFR) mutation-positive adenocarcinoma of the lung that continues to outlive stage IV diagnosis of non-small cell lung cancer after treatment with RRx-001, an experimental anticancer agent with epigenetic and immunologic activity, in the context of a phase II clinical trial called TRIPLE THREAT. Currently, no adequate treatment options exist for patients with EGFR mutation-positive tumors who have failed a 1st-generation tyrosine kinase inhibitor (erlotinib or gefitinib) treatment and do not develop a resistant mutation. Biopsy of a large pancreatic metastasis after RRx-001 demonstrated extensive necrosis with CD3+ and CD8+ immune cell infiltration that appears to correlate with prolonged survival despite end-stage disease. These results suggest that the mode of action of RRx-001 is related to immune stimulation in addition to epigenetic inhibition.


Brzezniak et al.: RRx-001-Induced Tumor Necrosis and Immune Cell Infiltration in an EGFR Mutation-Positive NSCLC with Resistance to EGFR Tyrosine Kinase Inhibitors

\section{Introduction}

Adenocarcinoma, the most common type of lung cancer, accounts for nearly half of all non-small cell lung cancer (NSCLC) cases [1]. With more than a million deaths per year [2], it is the leading cause of worldwide cancer-related mortality [3]. A common molecular subset of NSCLC, associated with 10 and 30\% of NSCLCs in North American/European and East Asian countries, respectively [4], harbors activating mutations in the epidermal growth factor receptor (EGFR) [5]. The two most common EGFR mutations are exon 19 deletions and the L858R point mutation, with exon 19 deletions leading to a longer survival following treatment with EGFR tyrosine kinase inhibitors (TKIs) compared with those with the L858R mutation [6].

Despite the dramatic efficacy of these TKIs, including erlotinib, gefitinib, and afatinib, in $70 \%$ of EGFR-mutant NSCLCs, the remaining 30\% exhibit de novo resistance [7] and, even among initial responders, acquired resistance is inevitable, usually in less than 1 year [8].

The present report describes the case of a patient with acquired resistance to carboplatin/pemetrexed and erlotinib who demonstrated massive necrosis during treatment with the systemically nontoxic epi-immunotherapeutic agent, RRx-001 [9-11], in the context of a clinical trial called TRIPLE THREAT (NCT02489903). The objective of this trial is to investigate resensitization to platinum doublet chemotherapy in patients with NSCLC, SCLC, and high-grade neuroendocrine tumors.

\section{Case}

A 49-year-old white male US Air Force Master Sergeant and never smoker was initially diagnosed with clinical stage IIIA (T3, N1, M0) EGFR-positive (exon 19 deletion) NSCLC in June 2014 in the left upper lobe of the lung, for which he underwent upper lobectomy followed by four cycles of carboplatin (AUC $=5)$ and pemetrexed $\left(500 \mathrm{mg} / \mathrm{m}^{2}\right)$ that finished on October 29, 2014. On December 1, 2014, due to complaints of upper abdominal pain and weight loss, a metastasis to the abdomen was discovered. Surgical resection was undertaken, and pathology confirmed an EGFR-positive metastasis from the primary lung cancer.

In June 2014, a computed tomography (CT) scan demonstrated a new mass in the pancreas. Cytology samples obtained via fine needle aspiration (FNA) demonstrated the presence of an EGFR exon 19 mutation-positive lung adenocarcinoma. Treatment with erlotinib (150 mg daily) was initiated on December 22, 2014. Restaging CT 8 weeks later revealed a decreased size of the metastasis. Approximately 6 months after starting erlotinib in July 2015, restaging CT revealed disease progression. Another FNA of the mass demonstrated persistence of the EGFR exon 19 mutation.

In August 2015, the patient was enrolled on a phase II clinical trial with TH-4000 [12], a hypoxia-activated EGFR/Her2 inhibitor, for patients who failed erlotinib therapy. Approximately 8 weeks later, restaging CT demonstrated disease progression, with a doubling in the size of the mass.

On October 8, 2015, despite a 20-lb weight loss and a decline in performance status due to the size of the mass, he enrolled on the TRIPLE THREAT trial (NCT02489903) and received $4 \mathrm{mg}$ of once weekly RRx-001. Five weeks later, due to progressively worsening abdominal pain, he was imaged with PET/CT, which demonstrated an enlarged necrotic mass in the head of the pancreas with a thin capsule of apparently viable tumor (fig. 1).

Image-guided aspiration of the mass yielded $200 \mathrm{ml}$ of fluid, which was sent for cytology. The fluid content was positive for a predominance of necrotic debris with CD8+ T-cell 
Brzezniak et al.: RRx-001-Induced Tumor Necrosis and Immune Cell Infiltration in an EGFR Mutation-Positive NSCLC with Resistance to EGFR Tyrosine Kinase Inhibitors

infiltration. A comparison of cellularity, necrosis, and T-cell infiltrate before and after treatment with RRx-001 is demonstrated graphically in figure 2, and the degree of necrosis in figure 3.

On November 10, 2015, due to this early pseudoprogression or apparent growth of the tumor from extensive necrosis, defined as RECIST v.1.1 progression, the patient was restarted on platinum doublets (cisplatin/pemetrexed) per protocol. Since the tumor is at least partially liquefied centrally, a percutaneous drainage catheter was placed leading to significant symptomatic improvement.

\section{Discussion}

While the prognosis for patients with EGFR-mutant NSCLC that have progressed on prior TKI therapy remains grim, evidence of efficacy with checkpoint inhibitors in NSCLC suggests that RRx-001, which induces antitumor immune responses, may provide a new treatment direction for NSCLC in general and EGFR-mutant NSCLC in particular, since the latter is reported to be associated with programmed death-ligand 1 (PD-L1) expression [13]. More detailed investigations of the functions of $\mathrm{T}$ and $\mathrm{B}$ cells and PD-1/L1 expression in the antitumor effects of RRx-001 are warranted to characterize the immune profile of these responders, which, in turn, may suggest new combination strategies to enhance the cancer immunity cycle [14]. As an epi-immunotherapeutic agent, RRx-001, like the DNA methyltransferase inhibitors decitabine [15] and azacytidine [16, 17], is associated with the production of interferon- $\gamma$ [18]. Although, in this study, patients received RRx-001 as monotherapy, the systemic non-toxicity of RRx-001, as well as the preclinical [18] and preliminary clinical evidence of immune reactivation in combination with nivolumab in a phase I doseescalation trial called PRIMETIME (NCT02518958), potentially provides a rationale for triple therapy with RRx-001, EGFR-TKIs, and anti-PD-1/PD-L1 antibodies in EGFR-mutant NSCLC.

\section{Statement of Ethics}

The case report was conducted according to the Declaration of Helsinki principles. The patient gave written informed consent.

\section{Disclosure Statement}

B.T.O., J.J.S. and S.Z.C. are employees of EpicentRx, Inc. EpicentRx, Inc. provided funding for the study.

\section{References}

1 Burris HA 3rd: Shortcomings of current therapies for non-small-cell lung cancer: unmet medical needs. Oncogene 2009;28(suppl 1):S4-S13.

2 Esposito L, Conti D, Ailavajhala R, Khalil N, Giordano A: Lung cancer: are we up to the challenge? Curr Genomics 2010;11:513-518.

-3 Molina JR, Yang P, Cassivi SD, Schild SE, Adjei AA: Non-small cell lung cancer: epidemiology, risk factors, treatment, and survivorship. Mayo Clin Proc 2008;83:584-594.

4 Ohashi K, Maruvka YE, Michor F, Pao W: Epidermal growth factor receptor tyrosine kinase inhibitorresistant disease. J Clin Oncol 2013;31:1070-1080. 


\section{Case Reports in Oncology}

\begin{tabular}{l|l}
\hline Case Rep Oncol 2016;9:45-50 \\
\hline DOI: 10.1159/000443605 & $\begin{array}{l}\text { C } 2016 \text { The Author(s). Published by S. Karger AG, Basel } \\
\text { www.karger.com/cro }\end{array}$ \\
\hline
\end{tabular}

Brzezniak et al.: RRx-001-Induced Tumor Necrosis and Immune Cell Infiltration in an EGFR Mutation-Positive NSCLC with Resistance to EGFR Tyrosine Kinase Inhibitors

5 Sharifnia T, Rusu V, Piccioni F, Bagul M, Imielinski M, Cherniack AD, Pedamallu CS, Wong B, Wilson FH, Garraway LA, et al: Genetic modifiers of EGFR dependence in non-small cell lung cancer. Proc Natl Acad Sci USA 2014;111:18661-18666.

6 Jackman DM, Yeap BY, Sequist LV, Lindeman N, Holmes AJ, Joshi VA, Bell DW, Huberman MS, Halmos B, Rabin MS, et al: Exon 19 deletion mutations of epidermal growth factor receptor are associated with prolonged survival in non-small cell lung cancer patients treated with gefitinib or erlotinib. Clin Cancer Res 2006;12:3908-3914.

7 Lin L, Bivona TG: Mechanisms of resistance to epidermal growth factor receptor inhibitors and novel therapeutic strategies to overcome resistance in NSCLC patients. Chemother Res Pract 2012;2012:817297.

-8 Stewart EL, Tan SZ, Liu G, Tsao MS: Known and putative mechanisms of resistance to EGFR targeted therapies in NSCLC patients with EGFR mutations - a review. Transl Lung Cancer Res 2015;4:67-81.

-9 Reid T, Oronsky B, Scicinski J, Scribner CL, Knox SJ, Ning S, Peehl DM, Korn R, Stirn M, Carter CA, et al: Safety and activity of RRx-001 in patients with advanced cancer: a first-in-human, open-label, dose-escalation phase 1 study. Lancet Oncol 2015;16:1133-1142.

10 Zhao H, Ning S, Scicinski J, Oronsky B, Knox SJ, Peehl DM: Epigenetic effects of RRx-001: a possible unifying mechanism of anticancer activity. Oncotarget 2015;6:43172-43181.

-11 Ning S, Bednarski M, Oronsky B, Scicinski J, Saul G, Knox SJ: Dinitroazetidines are a novel class of anticancer agents and hypoxia-activated radiation sensitizers developed from highly energetic materials. Cancer Res 2012;72:2600-2608.

12 Patterson AV, Silva S, Guise C, Abbattista M, Bull M, Hsu H-L, Hart C, Sun J, Grey A, Ashoorzadeh A, et al: The hypoxia-activated EGFR-TKI TH-4000 overcomes erlotinib-resistance in preclinical NSCLC models at plasma levels achieved in a phase 1 clinical trial (abstract 5358). Cancer Res 2015;75:5358.

13 Chen N, Fang W, Zhan J, Hong S, Tang Y, Kang S, Zhang Y, He X, Zhou T, Qin T, et al: Upregulation of PD-L1 by EGFR activation mediates the immune escape in EGFR-driven NSCLC: implication for optional immune targeted therapy for NSCLC patients with EGFR mutation. J Thorac Oncol 2015;10:910-923.

14 Chen DS, Mellman I: Oncology meets immunology: the cancer-immunity cycle. Immunity 2013;39:1-10. Gollob JA, Sciambi CJ: Decitabine up-regulates S100A2 expression and synergizes with IFN-gamma to kill uveal melanoma cells. Clin Cancer Res 2007;13:5219-5225.

-16 Chiappinelli KB, Strissel PL, Desrichard A, Li H, Henke C, Akman B, Hein A, Rote NS, Cope LM, Snyder A, et al: Inhibiting DNA methylation causes an interferon response in cancer via dsRNA including endogenous retroviruses. Cell 2015;162:974-986.

17 Roulois D, Loo Yau H, Singhania R, Wang Y, Danesh A, Shen SY, Han H, Liang G, Jones PA, Pugh TJ, et al: DNAdemethylating agents target colorectal cancer cells by inducing viral mimicry by endogenous transcripts. Cell 2015;162:961-973.

18 Knox SJ, Ning S, Peehl DM, Oronsky B, Scicinski J: RRx-001 combined with anti-PD-L1 antibody increases the complete response rate in a preclinical myeloma model (abstract C181). AACR-NCI-EORTC International Conference on Molecular Targets and Cancer Therapeutics, Boston, 2015. 


\section{Case Reports in Oncology}
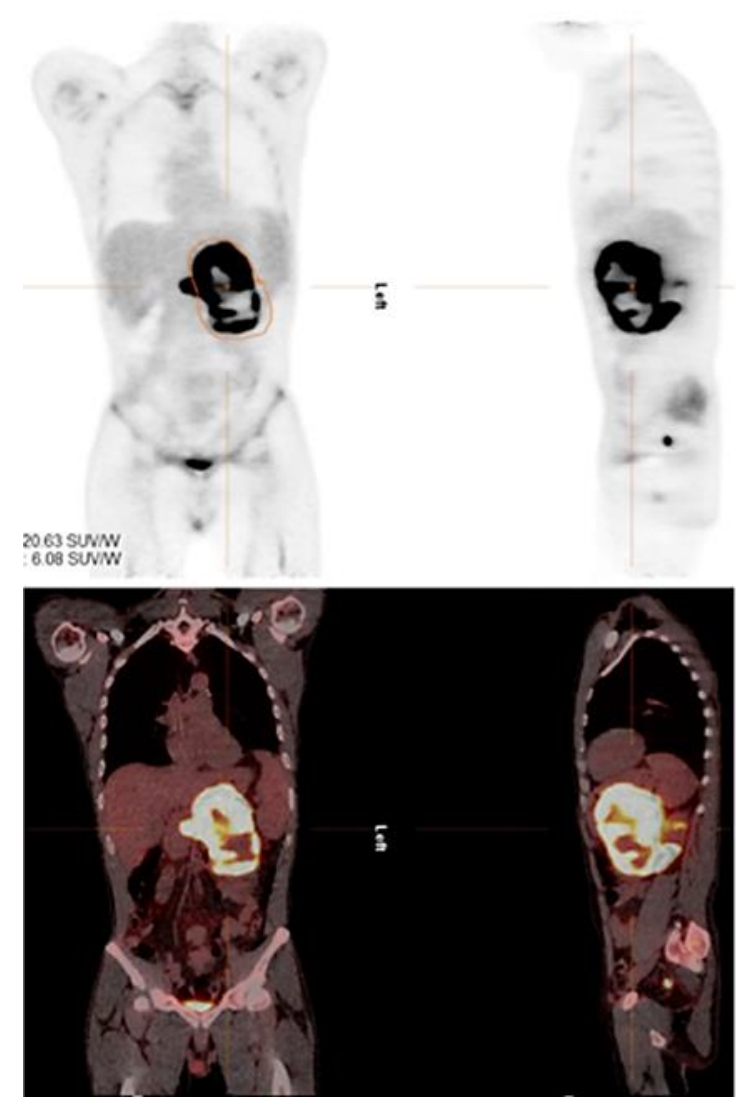
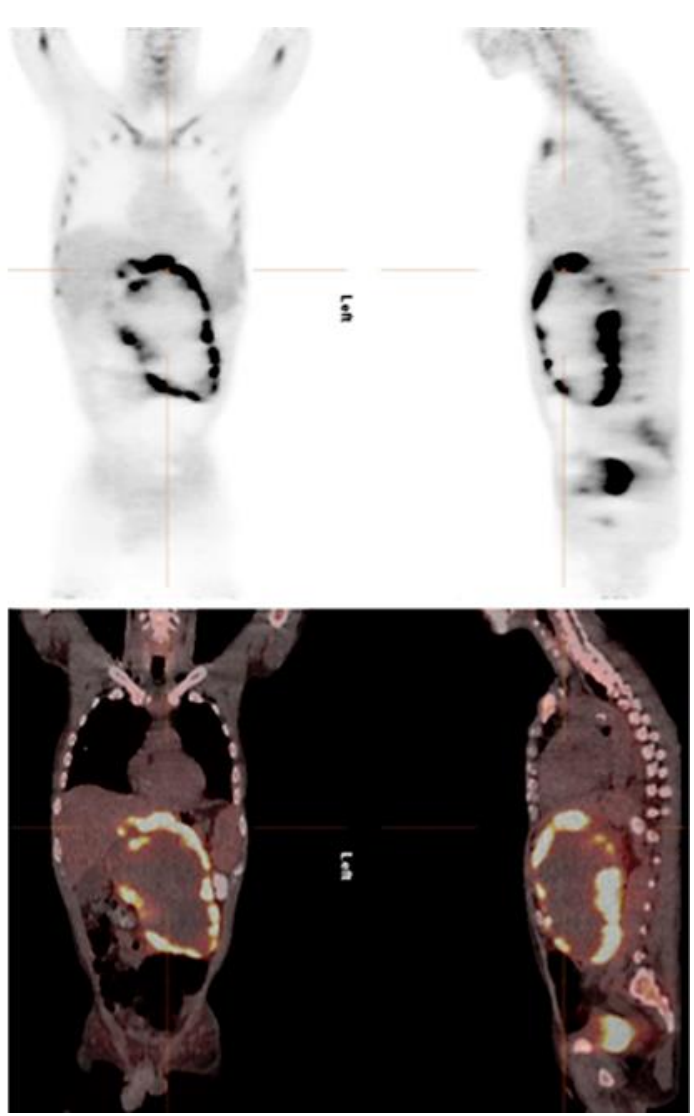

Fig. 1. Baseline FDG-PET/CT (left) demonstrating an FDG avid tumor is compared to interim FDG-PET/CT after 5 weeks of treatment with RRx-001 (right). The treatment effect is indicated by extensive central tumor necrosis with a thin halo of the apparently viable tumor.

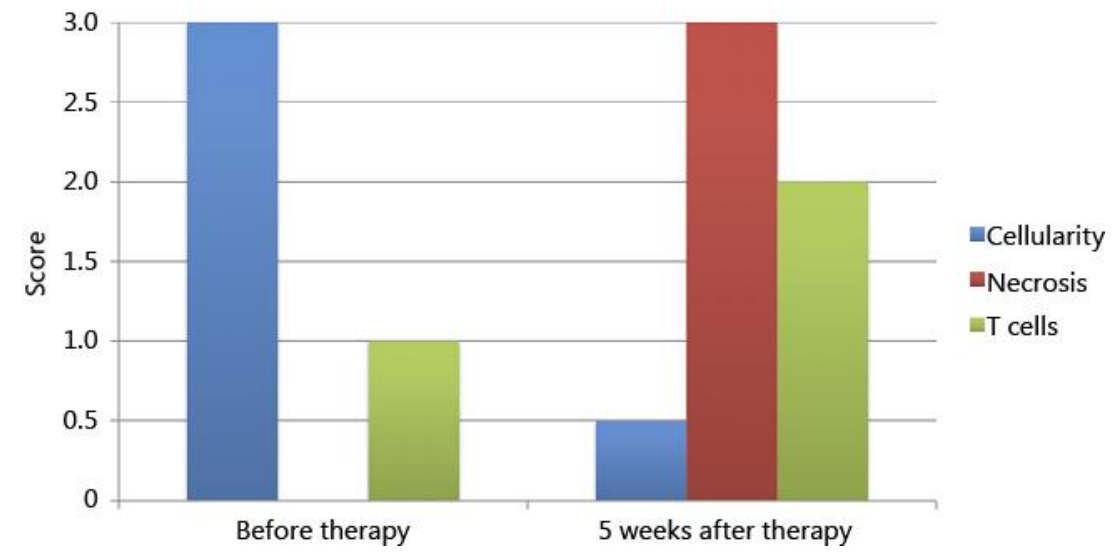

Fig. 2. Pancreatic FNA/cell block analysis. Scoring scale from 1 to 3 . Cellularity scale: Ki- 67 index, $<2 \%=$ $1,2-20 \%=2$, and $>20 \%=3$. Necrosis scale: punctuate $/$ focal $=1$, geographic $=2$, and widespread $=3$. T-cell scale: number of CD3+ T cells per high-power field $(\times 40), 1=$ low, $2=$ medium, and $3=$ high. 


\section{Case Reports in Oncology}

\begin{tabular}{l|l}
\hline Case Rep Oncol 2016;9:45-50 \\
\hline DOI: 10.1159/000443605 & $\begin{array}{l}\text { (c) 2016 The Author(s). Published by S. Karger AG, Basel } \\
\text { www.karger.com/cro }\end{array}$ \\
\hline
\end{tabular}

Brzezniak et al.: RRx-001-Induced Tumor Necrosis and Immune Cell Infiltration in an EGFR Mutation-Positive NSCLC with Resistance to EGFR Tyrosine Kinase Inhibitors

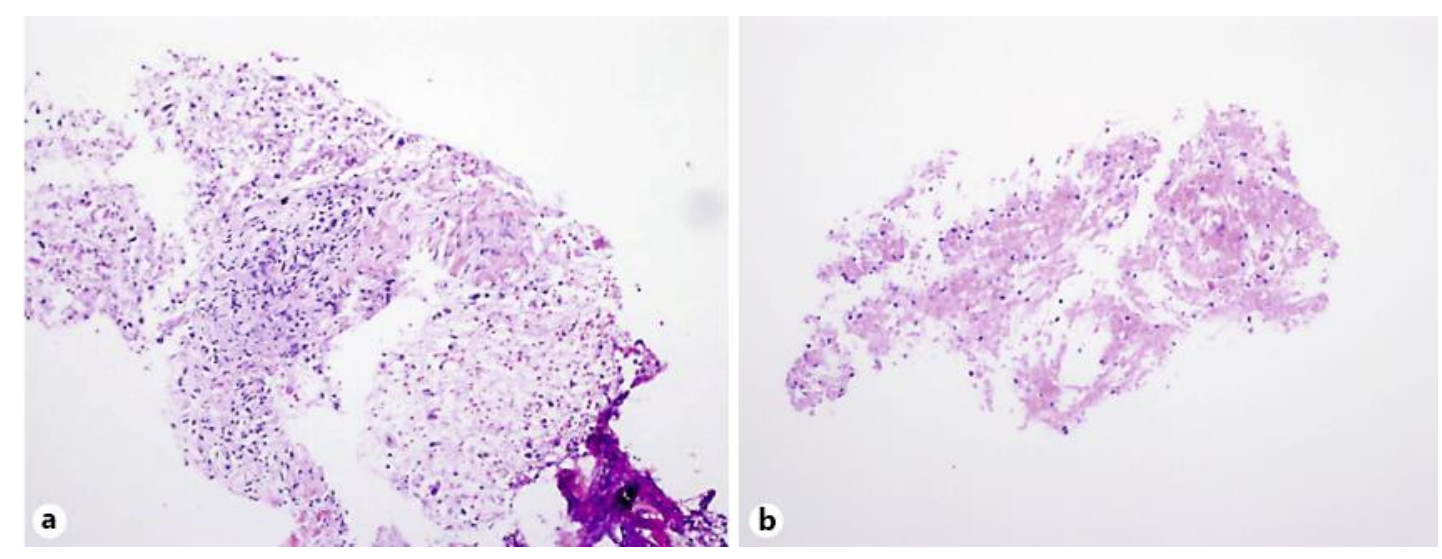

Fig. 3. Hematoxylin and eosin cell block staining before (a) and after therapy (b, 5 weeks from start of therapy) showing decreased cellular viability and a high degree of necrosis. 